\title{
Evaluating population and community structure against climate and land-use determinants to improve the conservation of the rare Narcissus pseudonarcissus subsp. nobilis
}

\author{
Ana Sofia Vaz ${ }^{* 1,2}$, Duarte Silva ${ }^{3}$, Paulo Alves ${ }^{1}$, Joana Raquel Vicente ${ }^{1}$, \\ Francisco Barreto Caldas ${ }^{1,2}$, João Pradinho Honrado ${ }^{1,2} \&$ Angela Lomba $^{1,4,5}$ \\ ${ }^{1} \mathrm{CIBIO} / \mathrm{InBIO}$ (Centro de Investigação em Biodiversidade e Recursos Genéticos da Universidade do \\ Porto/Laboratório Associado), Rua Padre Armando Quintas, PT-4485-661; Vairão, Portugal \\ ${ }^{2}$ Faculdade de Ciências da Universidade do Porto, Departamento de Biologia, Edifício FC4, sala 1A, Rua do Campo Alegre, S/N, PT-4169-007 Porto, Portugal \\ ${ }^{3}$ Floradata - Biodiversidade, Ambiente e Recursos Naturais, Lda., Rua do Campinho, 32 - $3^{\circ} \mathrm{F}, 4000-151$ Porto, Portugal \\ ${ }^{4}$ Alterra Wageningen University and Research Centre, NL-6708 Wageningen, The Netherlands \\ ${ }^{5}$ Départment d'Ecologie et d'Evolution (DEE), Université de Lausanne, CH-1015 Lausanne, Switzerland \\ asofia.vaz@fc.up.pt; duarteff@gmail.com; paulo.alves@fc.up.pt; jsvicente@fc.up.pt; fbcaldas@fc.up.pt; jhonrado@fc.up.pt; angelalomba@fc.up.pt
}

\begin{abstract}
Vaz, A.S., Silva, D., Alves, P., Vicente, J.R., Caldas, F.B., Honrado, J.P. \& Lomba, A. 2016. Evaluating population and community structure against climate and land-use determinants to improve the conservation of the rare Narcissus pseudonarcissus subsp. nobilis. Anales Jard. Bot. Madrid 73(1): e027.

Climate and land-use changes are among the most relevant determinants of future persistence of rare plant species in rural landscapes. We analysed the structure of populations of a rare plant, Narcissus pseudonarcissus subsp. nobilis, and of their respective plant communities against several environmental variables (climate-, topography-, land-use-, and soil-related) in order to identify the pressures that may directly or indirectly affect the persistence of the rare species. Overall, local land-use was the primary determinant of traits related to population renewal and community composition. Specifically, traditional farmlands supported higher community diversity and population individuals. Though moderate land-use intensification seemed to benefit plant community diversity, land abandonment could allow the persistence of $N$. pseudonarcissus subsp. nobilis populations. Also, a relevant influence of regional environment was perceived on species richness as well as on traits related to population condition, highlighting climate change as a potential determinant of the future persistence of the species. This study highlights the importance of considering key population traits as well as of community structure to accomplish conservation goals by accounting with the factors driving changes in the habitats in which rare species occur, from climate change to land-use and landscape management.
\end{abstract}

Keywords: Endangered species, Iberian Peninsula, land-use, population traits, rural landscapes

\section{INTRODUCTION}

European rural landscapes comprise a diversity of vegetation mosaics of high nature value, with species and habitats of conservation interest (Billeter \& al., 2008; Lomba $\&$ al., 2014). Still, these landscapes are under several pressures, from climate change to land-use modifications

\section{Resumen}

Vaz, A.S., Silva, D., Alves, P., Vicente, J.R., Caldas, F.B., Honrado, J.P. \& Lomba, A. 2016. Evaluando la estructura de la población y de la comunidad frente al clima y el uso del suelo para mejorar la conservación de una especie rara, Narcissus pseudonarcissus subsp. nobilis. Anales Jard. Bot. Madrid 73(1): e027.

Las alteraciones del clima y del uso del suelo están entre los factores más relevantes para la persistencia de las especies raras de plantas en paisajes rurales. Este trabajo evalúa la estructura de las poblaciones de una especie rara, Narcissus pseudonarcissus subsp. nobilis, así como de las comunidades de plantas en las cuales se incluyen, frente a variables ambientales (relacionadas con el clima, la topografía, el uso del suelo, y las propiedades del suelo), para identificar las presiones que puedan directa o indirectamente afectar a la especie. En general, el uso local del suelo fue el principal determinante de las características de las poblaciones relacionadas con la capacidad de renovación de esta subespecie, así como de la composición específica de las comunidades. Específicamente, la intensificación media de uso del suelo parece beneficiosa para la diversidad de las comunidades de plantas, pero el abandono agrícola parece permitir la presencia de las poblaciones de $N$. pseudonarcissus subsp. nobilis. Adicionalmente, una influencia relevante del ambiente regional fue observada para la riqueza específica, así como sobre las características de las condiciones actuales de las poblaciones, sugiriendo que la alteración del clima es un factor potencial para el futuro de la especie. Este estudio destaca la importancia de considerar características clave de las poblaciones así como de la estructura de las comunidades, lo que permite conseguir objetivos de conservación que incluyen factores de cambio en los hábitats, desde las alteraciones del clima y del uso del suelo hasta la gestión del paisaje.

Palabras clave: Características poblacionales, especies amenazadas, paisajes rurales, Península Ibérica, uso del suelo.

(Deutschewitz \& al., 2003; Lomba \& al., 2012). Specifically, the abandonment of traditional land-use and the intensification of already intensively managed land are among the main determinants of plant diversity (Vassilev \& al., 2011; Plieninger \& al., 2014).

Assessing the factors determining the patterns of plant diversity is thus a priority in current research and downstream 
decision making (Schneiders \& al., 2012; Smart \& al., 2012). However, resources needed for exhaustive surveys are often unavailable, and so indicator-based approaches have been considered due to their cost- and time-efficiency (Smart \& al., 2012; González-Oreja \& al., 2013). Indicator-based approaches rely on relations between the attributes of distinct levels of ecological organisation (e.g., populations, communities) and their environmental conditions at given spatial and temporal scales (González-Oreja \& al., 2013). The rationale is that, in the presence of a significant species-environment relation, when the environmental determinant is intensified or reduced, the attribute or pattern of the focal plant species or community will also change (Smart \& al., 2012; Hoare $\&$ al., 2013). For several plant taxa, such approaches have focused on traits which exhibit similar responses to environmental conditions or shifts (Gondard \& al., 2003; Cousins \& Lindborg, 2004; Albert \& al., 2010; Lavorel \& al., 2011).

Rare taxa constitute one of the key targets of conservation actions as they often exhibit high extinction risks associated to their small population sizes and restricted geographic ranges (Fontaine \& al., 2007; Lomba \& al., 2010). The persistence of rare plants has been related to population traits that frame their adaptive abilities, renewal capacities and responses to environmental shifts (Shipley \& al., 2006; Albert \& al., 2010). The assessment of such traits is thus essential for evaluating the condition and dynamics of rare plant populations, and also of the plant communities of which they are part of (Shipley \& al., 2006; Violle \& al., 2007). The persistence of rare plants has also been related to changes in the habitats in which they occur (Fontaine $\&$ al., 2007; Lomba \& al., 2010). From a conservation perspective, effective planning and monitoring should consider not only the factors directly affecting the structure of rare plant populations, but also the determinants of their habitats (Broennimann \& al., 2005; Regnery \& al., 2013). In fact, several initiatives have adopted this approach in important policy instruments such as the EU Habitats Directive (Council Directive 92/43/EEC) and the IUCN European Red Data list (Bilz \& al., 2011).

In this study, we aimed at evaluating the determinants of population structure for Narcissus pseudonarcissus L. subsp. nobilis (Haw.) A. Fernandes, a rare, endangered plant under legal protection, as well as of the plant communities of which the populations are part of. By doing so, we expected to identify the environmental and biotic pressures that may directly or indirectly threaten this plant, thereby addressing common conservation strategies in Portuguese rural landscapes. This taxon, sometimes recognized at the species level as N. nobilis (Haw.) Schult. \& Schult. fil., is an Iberian endemic plant of European conservation interest, and is considered a rare and threatened species for Portugal (ICNF, 2006). The recent treatment for Narcissus in Flora Iberica (Aedo, 2013) assumes this name as a synonym of $N$. pseudonarcissus subsp. pseudonarcissus, however, given the synthetic approach adopted in that work, we prefer to preserve the use of subsp. nobilis rather than merge it in the typical subspecies. This endemic daffodil has been under several anthropogenic threats (Lozano \& al., 1996), which are expected to be aggravated due to future scenarios of land-use change (Bielsa, 2005; Lomba \& al., 2012). An analytical framework is proposed that integrates several population traits of the target species as well as several potential determinants operating at distinct scales. The implications of our results and of the novel framework for the conservation and management of subsp. nobilis and other rare, threatened plants are also discussed.

\section{METHODS}

\section{Study area}

The study was conducted in seven sites located in the Northwestern and the Central Portugal (Fig. 1). The Northwestern Portugal is characterised by the biogeographic transition between the Eurosiberian (coinciding with a temperate Atlantic climate) and the Mediterranean regions. This area comprises the only Portuguese National Park, Peneda Gerês, and the Natura 2000 site of Corno do Bico (ICNF, 2012). One site (Videmonte) was located in Central Portugal, specifically in the Natural Park of Serra da Estrela (ICNF, 2012), a mountain area characterised by interchanges between the Atlantic and the Mediterranean climates.

In the ensemble of the seven sites, the altitude ranges from 20 to $1190 \mathrm{~m}$, the mean annual temperature spans from 8.75 to $11.25^{\circ} \mathrm{C}$, and granite is the prevailing bedrock type. Further details on the surveyed sites are presented in Table 1.

\section{Target populations}

Narcissus pseudonarcissus subsp. nobilis (subsp. nobilis hereafter) is an herbaceous and bulbous geophyte, typically occurring in semi-natural grasslands (Honrado, 2003). Populations are usually organised in tuffs i.e., groups of individuals with a maximum distance of $2 \mathrm{~cm}$ between them. The aerial structure of each $N$. pseudonarcissus subsp. nobilis individual may comprise one, two or at least three leaves, corresponding to juvenile, sub-adult, and adult individuals, respectively (Barkham, 1980a). During the flowering season of the species (April-July) each adult may exhibit a bicolored flower with pale yellow tepals and a golden yellow corona, with or without capsules and seeds (Hanks, 2002). $N$. pseudonarcissus subsp. nobilis is an Iberian endemic plant (ICNF, 2006) restricted to the northern half of the Iberia Peninsula (Hanks, 2002; Aedo, 2013), where their populations and habitat have been under several pressures, mostly expressed by the collection of flowers, wildfires and landuse changes (Lozano \& al., 1996). The species is a Least Concern for Europe (IUCN criteria; Bilz \& al., 2011) and a rare and threatened species for Portugal (ICNF, 2006), being under legal protection (EU Directive 92/43/EEC).

\section{Sampling design and data collection}

First, seven sites were selected based on a literature review and previous records on the occurrence of subsp. nobilis populations (e.g., Barkham, 1980a, b; Castroviejo \& al., 1986-2010; Barkham, 1992; Hank, 2002). These records were confirmed in the field and the population was mapped in each site. Then, based on aerial imagery (http:// scrif.igeo.pt/servicos/localiz/), a grid of $25 \mathrm{~m}^{2}$ cells was considered and overlapped to each site in order to cover the whole extent of each population (see Appendix 1 for the considered images and grids). At each site, five $25 \mathrm{~m}^{2}$ grid 


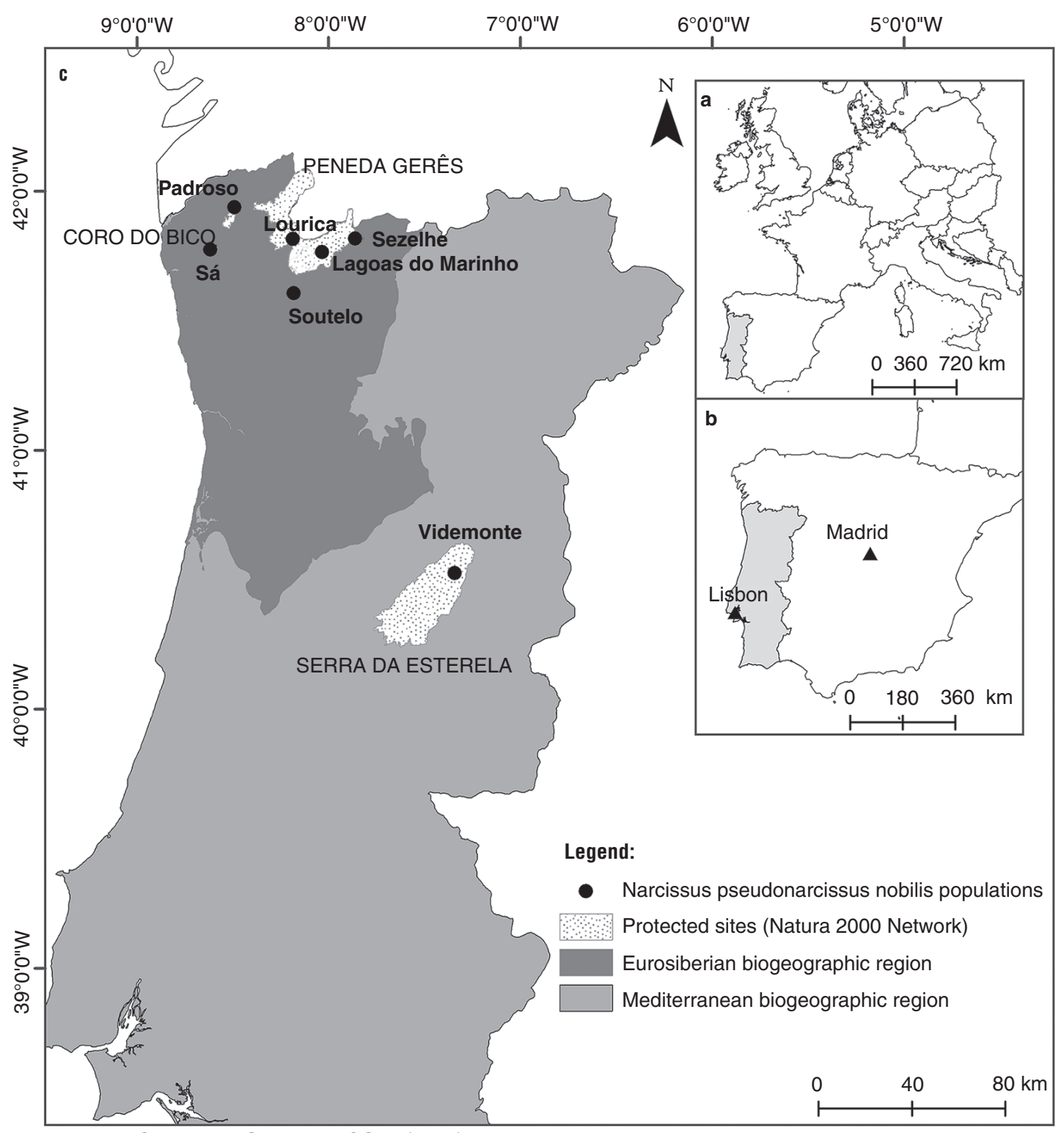

Projected Coordinate System: WGS84 (UTM) Zone 29N

Fig. 1. Location of the study area in Europe, $\mathbf{a}$; and in the Iberian Peninsula, $\mathbf{b}$. The fig. also shows the location of the sampling sites, the protected areas (Peneda Gerês, Corno do Bico, and Serra da Estrela), and the main biogeographic regions, Eurosiberian and Mediterranean, $\mathbf{c}$.

cells were selected for detailed surveys, thus resulting in a total of 35 sampling plots $(n=35)$, which was considered representative of each population variability. These procedures were implemented in ArcGIS 10 (ESRI, 2010).

In each plot, nine population traits (sensu "demographic parameter" from Violle \& al., 2007) were measured following in-field standardised protocols (e.g., Cornelissen \& al., 2003). These traits (Table 2) were selected as they express the condition, renewal capacity, and disturbance on renewal of subsp. nobilis populations (Barkham, 1980a, b, 1992; Hanks, 2002; Colling \& al. 2010). The surveillance effort for these traits was proportional to the density of the populations surveyed in each site.

A complete list of vascular plant species was also recorded at each plot. The \% cover of each species was measured following a simplified Domin scale (Kent \& Coker, 1992):
(1)<1\%, (2) $1-5 \%$, (3) $6-15 \%$, (4) $16-25 \%$, (5) $26-50 \%$, (6) $51-75 \%$, (7) $76-90 \%$, (8) $91-100 \%$. Species nomenclature generally followed Castroviejo et al. (1986-2010).

\section{Habitats surveyed and underlying land-use}

Based on in-field observations, each plot was classified according to their dominant habitat/vegetation type. Five different habitat types were considered that expressed a gradient of land-use intensity: from the extensively managed hay meadows and tall scrub, to the more intensively managed grazed meadows, wet heaths and crop fields (see Table 1). The 35 surveyed plots were distributed as: (1) tall scrub $(n=5),(2)$ wet heaths $(n=5),(3)$ extensive meadows $(n=15),(4)$ intensive meadows $(n=5),(5)$ and crop fields $(n=5)$. Though unbalanced, this set of habitats spanned 
Table 1. Details on the surveyed sites with coordinates, number of $25 \mathrm{~m}^{2}$ grid cells occupied by the population, environmental characterisation and dominant habitat type.

\begin{tabular}{|c|c|c|c|c|c|c|c|}
\hline Site & $\begin{array}{c}\text { Coordinates } \\
\text { (UTM) }\end{array}$ & $\begin{array}{l}\text { Number of } \\
\text { grid cells }\end{array}$ & $\begin{array}{l}\text { Area } \\
\left(\mathrm{m}^{2}\right)\end{array}$ & $\begin{array}{c}\text { Total annual } \\
\text { precipitation }(\mathrm{mm})\end{array}$ & $\begin{array}{c}\text { Mean annual } \\
\text { temperature }\left({ }^{\circ} \mathrm{C}\right)\end{array}$ & $\begin{array}{c}\text { Altitude } \\
(\mathrm{m})\end{array}$ & Habitat type \\
\hline Louriça & 29TNG7924 & 14 & 350 & 2600 & 11.25 & 1125 & Tall scrub \\
\hline Lagoas do Marinho & 29TNG6630 & 208 & 5250 & 2600 & 8.75 & 1190 & Wet heaths \\
\hline Padroso & 29TNG4143 & 226 & 5650 & 2200 & 11.25 & 655 & Extensive meadows \\
\hline Sá & 29TNG3125 & 28 & 700 & 1800 & 13.75 & 20 & Crop fields \\
\hline Sezelhe & 29TNG9329 & 74 & 1850 & 1800 & 11.25 & 990 & Intensive meadows \\
\hline Videmonte & 29TPE3687 & 141 & 3575 & 900 & 8.75 & 1050 & Extensive meadows \\
\hline
\end{tabular}

Table 2. Traits measured for the N. pseudonarcissus subsp. nobilis populations.

\begin{tabular}{|c|c|c|}
\hline Trait type & Population trait & Acronym \\
\hline \multirow[t]{3}{*}{ Population condition } & Number of individuals & Ind \\
\hline & Number of tuffs & Tuf \\
\hline & Number of individuals per tuff & IndTuf \\
\hline \multirow[t]{5}{*}{ Population renewal } & Number of juvenile individuals & Juv \\
\hline & Number of sub-adult individuals & SAdul \\
\hline & Number of adult individuals & Adul \\
\hline & Number of individuals with flowers & Flow \\
\hline & Number of individuals with capsules & Cap \\
\hline Disturbance on population renewal & Number of individuals with flowers without capsules & NCap \\
\hline
\end{tabular}

through the whole range of ecological variation known for this taxon across the study area, and was thus considered suitable to address our research goals, as it expresses different levels of land-use intensity where the targeted populations occur.

In short, tall scrub corresponds to plant communities characterised by a canopy of Genista florida L. and Erica arborea L., and by an herbaceous undergrowth dominated by the bentgrass, Agrostis x fouilladei P. Fourn. These habitats are usually under low-intensity management, mostly controlled grazing and burning (Honrado \& al., 2002). Wet heaths comprise temperate Atlantic low scrub dominated by Erica ciliaris Loefl. ex L. and E. tetralix L., and correspond to habitat type 4020* in Annex I of the "Habitats Directive" (EU Directive 92/43/EEC). Management often includes burning, domestic cutting and grazing (Hampton 2008). Extensively managed meadows are dominated by typical lowland mesohygrophilous grasses of the Arrhenatherion Koch phytosociological alliance (Rodríguez-Rojo \& SánchezMata, 2004), corresponding to habitat type 6510. These meadows are mostly managed for hay (Aguiar \& al., 2000). Under more intensive management (often involving grazing and fertilising), meadows show the dominance of plants of the Cynosurion cristati Tüxen alliance, e.g. Hypochoeris radicata L. and Cynosurus cristatus L. (Rodríguez-Rojo \& Sánchez-Mata, 2004; Aguiar \& al., 2010). Finally, crop fields comprise cover crops usually used for silage, and dominated by corn (summer crop) or the annual ryegrass, Lolium multiflorum Lam. (winter crop); the corn marigold, Coleostephus myconis (L.) Rchb.f., is the prevailing ruderal weed (Honrado \& al., 2002).

\section{Environmental variables}

Eighteen environmental variables were considered based on their potential effects on subsp. nobilis populations and coexistent plant community. Considering their spatial resolution, each variable was assigned to: (1) a regional context, mostly related to climate and topography, (2) a local context, related to land-use intensity, or (3) a sub-local context, related to soil properties (Lomba \& al., 2010). Climatic variables were extracted from Atlas do Ambiente (1:1000000 resolution; http://sniamb.apambiente.pt/webatlas). Altitude was obtained from military maps (1:25000 resolution; http:// www.igeoe.pt/). Land-use intensity was evaluated based on site-specific expert knowledge, considering the main landuse activities underlying each surveyed habitat: ploughing, seeding/planting, fertilising, irrigating, cutting, grazing, and burning. For each activity, a rank value of 0 (absent), 1 (occasionally) or 2 (frequently) was assigned, based on the relative intensity of each activity in each habitat. The final intensity value for each habitat was then computed by summing the rank values of each habitat, and then dividing it by the highest value attained (Table 3 ).

Soil properties were measured from soil samples (i.e., three to four cores $0.05-0.25 \mathrm{~m}$ horizon) for each $25 \mathrm{~m}^{2}$ cell, and analysed following standard procedures from the IPVC laboratory (http://portal.ipvc.pt/portal/page/portal/esa). All variables were tested for pair-wise correlations using Kendall's $T$ tests (non-parametric, suitable for a low number of observations; Quinn \& Keough, 2002). Variables with correlation values above 0.70 (i.e., Calcium content, Days of frost, and Insolation) were not considered in subsequent 
Table 3. Habitat types and correspondent habitat code from the Annex I of the "Habitats Directive". The table shows the values attributed to each habitat type considering their land-use activities. The ranked values were assigned based on the relative annual frequency of each activity: 0, absent; 1 , occasionally; 2, frequently. For each habitat, the final intensity value (expressed in a \% scale) was obtained by summing all the ranked values per habitat and then dividing it by the highest value attained.

\begin{tabular}{lccccc}
\hline & \multicolumn{5}{c}{ Habitat } \\
\cline { 2 - 6 } Land-use activity & Tall scrub & $\begin{array}{c}\text { Wet heaths (Habitat } \\
\text { code: } \mathbf{4 0 2 0 ^ { * } )}\end{array}$ & $\begin{array}{c}\text { Extensive } \\
\text { meadows (6510) }\end{array}$ & $\begin{array}{c}\text { Intensive } \\
\text { meadows }\end{array}$ & $\begin{array}{c}\text { Crop } \\
\text { fields }\end{array}$ \\
\hline Ploughing & 0 & 0 & 0 & 0 & 2 \\
Seeding/planting & 0 & 0 & 0 & 0 & 2 \\
Fertilising & 0 & 0 & 1 & 2 & 2 \\
Irrigating & 0 & 0 & 1 & 1 & 2 \\
Cutting & 0 & 1 & 2 & 1 & 2 \\
Grazing & 1 & 2 & 1 & 2 & 0 \\
Burning & 1 & 1 & 0 & 0 & 0 \\
Sum & 2 & 4 & 5 & 6 & 10 \\
Intensity value (\%) & 20 & 40 & 50 & 60 & 100 \\
\hline
\end{tabular}

Table 4. Environmental variables considered for analysing both population and community structure: type, units, acronym, and source/resolution.

\begin{tabular}{|c|c|c|c|}
\hline Variable type & Variable (units) & Acronym & Source / resolution \\
\hline \multicolumn{4}{|l|}{ Regional context } \\
\hline \multirow[t]{7}{*}{ Climate } & Total annual precipitation (mm) & Ptot & \multirow{7}{*}{$\begin{array}{l}\text { Atlas do Ambiente; } 1: 1000000 \\
\text { resolution; http://sniamb. } \\
\text { apambiente.pt/webatlas }\end{array}$} \\
\hline & Days of precipitation & Pdays & \\
\hline & Humidity of air (\%) & Hum & \\
\hline & Evapotranspiration (mm) & Evap & \\
\hline & Mean annual temperature $\left({ }^{\circ} \mathrm{C}\right)$ & Tmean & \\
\hline & Days of frost (day) & Gea & \\
\hline & Insolation (hours) & Inso & \\
\hline Topography & Altitude $(\mathrm{m})$ & Alt & $\begin{array}{l}\text { Military maps; } 1: 25000 \\
\text { resolution; www.igeoe.pt/ } \\
\text { cartoteca/cartogramaM888.htm }\end{array}$ \\
\hline \multicolumn{4}{|l|}{ Local context } \\
\hline Land-use & Land-use intensity (ranked scale) & LUint & $\begin{array}{l}\text { Land cover from aerial imagery } \\
\text { and field validation }\end{array}$ \\
\hline \multicolumn{4}{|l|}{ Sub-local context } \\
\hline \multirow[t]{9}{*}{ Soil properties } & Soil pH & $\mathrm{pH}$ & \multirow{9}{*}{$\begin{array}{l}\text { Soil samples analysed for each } \\
25 \mathrm{~m}^{2} \text { vegetation plot }\end{array}$} \\
\hline & Organic matter content (\%) & OM & \\
\hline & Phosphorous content (ug/g) & $P$ & \\
\hline & Potassium content (ug/g) & K & \\
\hline & Calcium content (ug/g) & $\mathrm{Ca}$ & \\
\hline & Magnesium content (ug/g) & MG & \\
\hline & Nitrogen content (ug/g) & $\mathrm{N}$ & \\
\hline & Soil moisture (\%) & $\mathrm{H}_{2} \mathrm{O}$ & \\
\hline & Soil density $\left(\mathrm{g} / \mathrm{cm}^{3}\right)$ & Dens & \\
\hline
\end{tabular}

analyses (Lomba et al. 2010), resulting in a final set of 15 environmental variables (Table 4).

\section{Analytical framework and statistical analyses}

An analytical framework was applied for assessing both population and community structure against the considered environmental variables. Since the observed data did not follow a normal distribution, only non-parametric tests and descriptive statistics were considered. Furthermore, considering that the set of habitat types was unbalanced, and to avoid any negative effects on the statistical procedures, all analyses were performed at the site level. Accordingly, significant differences for the number of subsp. nobilis individuals and community species richness (expressed as median \pm interquartile) were analysed across sites, using 
Kruskal-Wallis $(H)$ and post-hoc Mann-Whitney $(U)$ tests. A Detrended Correspondence Analysis (DCA) was implemented in order to analyse variations in population traits and community composition (i.e., species richness and abundance) along the considered environmental gradients (ter Braak \& Smilauer, 2002; Kleyer \& al., 2012). Finally, correlations between individual population traits and each environmental variable, as well as between community species richness and individual variables were analysed through Kendall's $T$ tests. For community composition, correlation values between DCA axes and environmental variables were assessed through weight correlation matrices as described in ter Braak \& Smilauer (2002). Univariate and multivariate statistical analyses were implemented in IBM SPSS Statistics 20 software (IBM Corp. Released, 2011) and CANOCO 4.5 software (ter Braak \& Smilauer, 2002), respectively.

\section{RESULTS}

\section{Population size per site and habitat type}

A total of 20319 N. pseudonarcissus subsp. nobilis individuals, organised in 4557 tuffs, was recorded. The highest median values of individuals per plot were observed for extensive meadows (Videmonte: 1025 \pm 3465 , Padroso: $594 \pm 647$ and Soutelo: $384 \pm 198$ ), and tall scrub (Louriça: $588 \pm 559)$. The lowest values were found for intensive meadows (Sezelhe: 95 \pm 152 ), wet heaths (Lagoas do Marinho: $75 \pm 201$ ) and crop fields (Sá: $7 \pm 45$ ). With the exception of Soutelo, the inter-quartile range was higher than the median in all sites. Kruskal-Wallis and post-hoc Mann-Whitney tests indicated significant differences between most sites (Appendix 2).

\section{Community structure along environmental gradients}

Overall, 181 plant species were recorded (Appendix 3). Videmonte (extensive meadows: $22 \pm 7$ ), Sezelhe (intensive meadows: $17 \pm 3$ ), Lagoas do Marinho (wet heaths: $15 \pm 2$ ) and Soutelo (extensive meadows: $14 \pm 3$ ) were the sites with the highest median values for species richness per vegetation plot, followed by Padroso (extensive meadows: 13 \pm 10 ), Sá (crop fields: $12 \pm 1$ ) and Louriça (tall scrub: $12 \pm 0$ ). KruskalWallis and post-hoc Mann-Whitney tests indicated significant differences among most sites, with the exception of Padroso (Appendix 2).

The projection of plant community composition in the ordination space showed that the surveyed plots were mostly distributed along the second DCA axis (DCA2; Fig. 2). From the top to the bottom, the DCA plot showed the segregation of plant communities from the different habitat types: (1) tall scrub, with Agrostis x fouilladei, Genista florida and Erica arborea for Louriça; (2) temperate Atlantic wet heaths, with Erica tetralix and Ulex minor Roth, for Lagoas do Marinho; (3) extensively managed meadows, with Anthoxanthum odoratum L. and Plantago lanceolata L., for Videmonte, Soutelo, Sezelhe and Padroso; and finally, (4) intensively managed meadows, with Hypochoeris radicata L. and Cynosurus cristatus L., for Sezelhe. From the left to the right and along the first DCA axis (DCA1), the segregation of crop fields, with

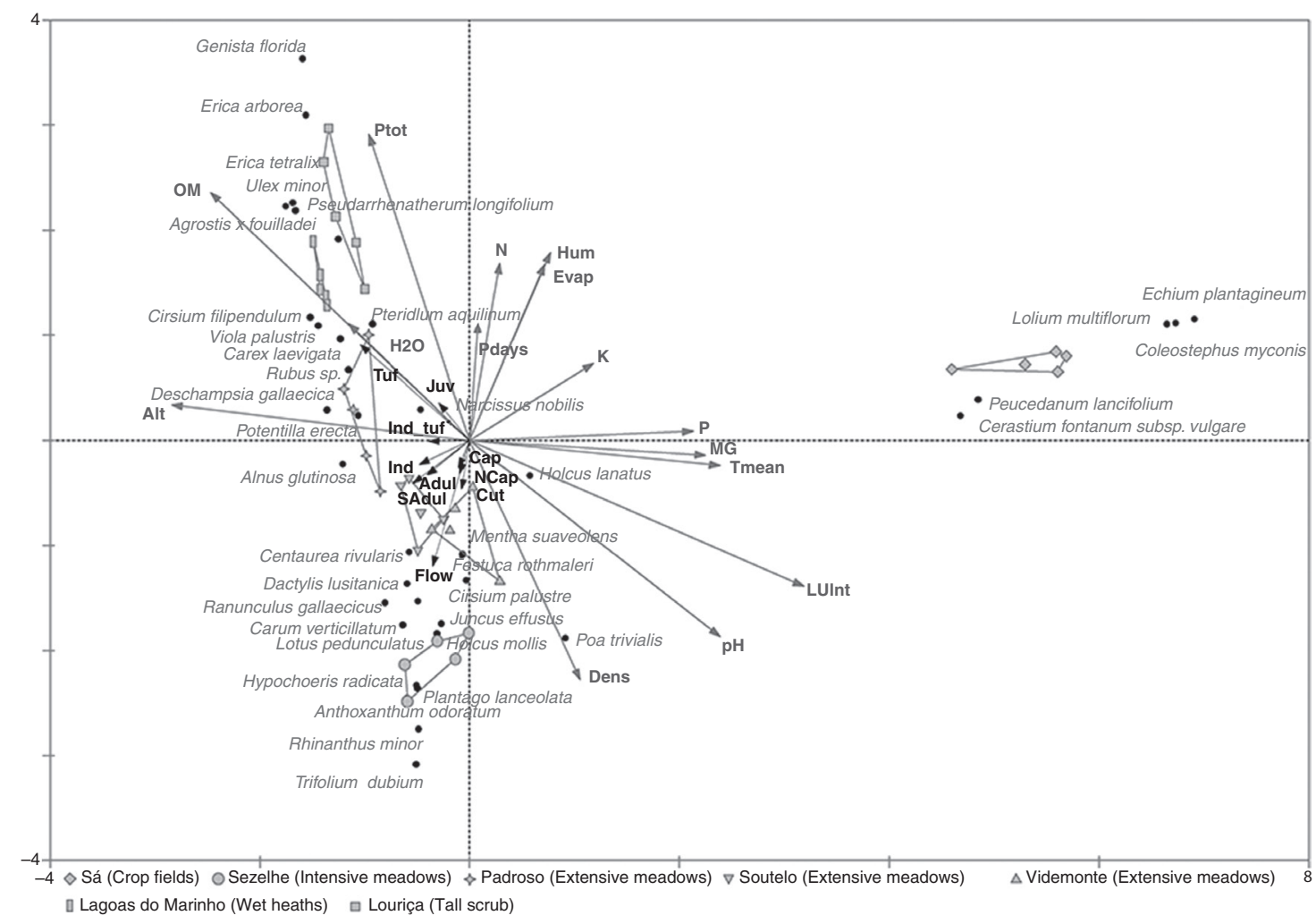

Fig. 2. Detrended Correspondence Analysis plot (DCA1/DCA2) of plant community composition across the surveyed sampling plots, with environmental variables and population traits. Only species with a minimum weight range of 10\% are shown (ter Braak \& Smilauer 2002). Distinct symbols represent different sites and are enclosed by the drawn polygons. 
Lolium multiflorum and Coleostephus myconis, for Sá was observed relatively to the other habitats.

A value of $24 \%$ of cumulative variance explained was found for the four DCA axes (eigenvalues: DCA1, 0.80; DCA2, 0.57; DCA3, 0.36; DCA4, 0.23 standard deviation). The cumulative $\%$ variance of the species-environment relationship explained by DCA 1 and DCA2 was $16 \%$ and $26 \%$. Both axes depicted variations related to regional, local and sub-local environmental variables. DCA1 was mostly correlated with land-use intensity, soil organic matter, soil $\mathrm{pH}$, and altitude. DCA2 had the highest correlation values with soil- (nitrogen, $\mathrm{pH}$, potassium, and moisture contents) and climate-related (evapotranspiration) variables (Table 5).

Kendall's correlation tests between community species richness and individual variables resulted in significant and negative values for all regional variables $(p<0.05)$, and for soil nitrogen content $(\tau=-0.37, p<0.05)$.

\section{Population structure along environmental gradients}

In the DCA plot, values for all population traits were found to increase towards sampling plots from extensive meadows (Fig. 2). The significant correlations between each population trait and individual variables are presented in Table 6. At the regional context, most traits were significantly and negatively correlated with mean annual temperature. Traits related to population condition and population renewal were negatively correlated with other climatic variables (Ptot, Pdays, Hum, Evap). At the local context, landuse intensity showed negative correlations with traits from

Table 5. Correlation values obtained between the main Detrended Correspondence Analysis axes (DCA1/DCA2) and each environmental variable.

\begin{tabular}{lllrr}
\hline Variable type & Environmental variable & Acronym & DCA1 & DCA2 \\
\hline Regional context & & & & \\
Climate & Total annual precipitation & Ptot & -0.556 & 0.021 \\
& Days of precipitation & Pdays & -0.176 & 0.174 \\
& Humidity of air & Hum & -0.007 & -0.175 \\
& Evapotranspiration & Evap & 0.004 & 0.366 \\
& Mean annual temperature & Tmean & 0.504 & -0.218 \\
Topography & Altitude & Alt & -0.712 & -0.034 \\
Local context & & & & \\
Land-use & Land-use intensity & LUint & 0.852 & -0.194 \\
Sub-local context & & & & \\
Soil properties & Soil pH & pH & 0.731 & -0.400 \\
& Organic matter content & OM & -0.795 & -0.032 \\
& Phosphorous content & P & 0.501 & -0.077 \\
& Potassium content & K & 0.257 & 0.367 \\
& Magnesium content & MG & 0.565 & 0.111 \\
& Nitrogen content & N & -0.066 & 0.507 \\
& Soil moisture & H2O & -0.405 & -0.326 \\
& Soil density & Dens & 0.415 & 0.110 \\
\hline
\end{tabular}

Table 6. Kendall's test results for the correlations between population traits and environmental variables. Only variables with at least one significant correlation with one population trait are shown. Statistical significance: ${ }^{\star} p<0.05,{ }^{*} p<0.01$.

\begin{tabular}{|c|c|c|c|c|c|c|c|c|c|c|c|c|}
\hline \multirow[b]{2}{*}{ Trait type } & \multirow[b]{2}{*}{ Traits } & \multicolumn{6}{|c|}{ Regional variables } & \multirow{2}{*}{$\begin{array}{c}\begin{array}{c}\text { Local } \\
\text { variables }\end{array} \\
\text { LUInt }\end{array}$} & \multicolumn{4}{|c|}{ Sub-local variables } \\
\hline & & Ptot & Pdays & Hum & Evap & Tmean & Alt & & OM & $\mathrm{pH}$ & K & MG \\
\hline \multirow[t]{3}{*}{ Population condition } & Ind & -0.13 & $-0.34^{*}$ & -0.14 & -0.14 & $-0.47 * *$ & 0.19 & -0.20 & 0.23 & -0.11 & -0.01 & $-0.36 * *$ \\
\hline & Tuf & -0.10 & $-0.29 *$ & -0.01 & -0.10 & $-0.36 * *$ & 0.19 & -0.19 & $0.26^{*}$ & -0.06 & 0.04 & -0.32 ** \\
\hline & IndTuf & $-0.26^{\star}$ & -0.26 & $-0.39 * *$ & -0.25 & $-0.34^{*}$ & 0.04 & -0.13 & -0.07 & -0.19 & -0.19 & -0.09 \\
\hline \multirow[t]{4}{*}{ Population renewal } & Juv & -0.01 & -0.13 & 0.01 & -0.04 & -0.22 & 0.11 & -0.10 & 0.10 & -0.08 & -0.10 & $-0.25^{\star}$ \\
\hline & Adul & -0.13 & $-0.31 *$ & -0.12 & -0.07 & $-0.47 * *$ & 0.18 & $-0.23^{*}$ & $0.24^{\star}$ & -0.12 & 0.02 & $-0.34 * *$ \\
\hline & Flow & 0.08 & -0.13 & $-0.34^{\star}$ & $-0.56 * *$ & -0.06 & 0.27 & -0.10 & -0.02 & 0.09 & $-0.39 * *$ & -0.13 \\
\hline & Cap & 0.00 & -0.25 & -0.11 & -0.11 & $-0.45^{* *}$ & $0.27 *$ & $-0.26^{\star}$ & $0.34^{* *}$ & -0.17 & 0.02 & $-0.34^{* *}$ \\
\hline $\begin{array}{l}\text { Disturbance on } \\
\text { population renewal }\end{array}$ & NCap & -0.20 & -0.26 & -0.16 & 0.02 & $-0.42 * *$ & 0.09 & $-0.24^{*}$ & 0.08 & $-0.32^{*}$ & 0.01 & -0.22 \\
\hline
\end{tabular}


population renewal and disturbance on population renewal. At the sub-local context, soil $\mathrm{pH}$ was only significantly correlated with traits from disturbance on population renewal; and potassium context only correlated with population renewal traits (negative correlations). Soil magnesium was negatively correlated with population condition and population renewal traits. Finally, organic matter content was positively correlated with population condition and population renewal traits, yet a negative correlation was found regarding traits from disturbance on population renewal.

\section{Main factors influencing population and community structure}

Table 7 shows the general results obtained when evaluating the structure of subsp. nobilis populations and plant communities in relation to their underlying environmental variables. Overall, higher values of both population and community structure were found in extensive meadows. Though the number of individuals was also found to be high in less managed habitats, plant community was found to be favoured by habitats under more intensive land-use.

Values for traits expressing the condition and the renewal capability of subsp. nobilis and for community species richness were negatively related with precipitation and temperature. Land-use was significantly and negatively related with population renewal traits and community composition. Organic matter related positively with population traits expressing subsp. nobilis current condition and renewal, and community composition. Other soil properties (mostly soil nutrients) were negatively related with both population and community structure.

\section{DISCUSSION}

\section{Population structure of rare plants}

Categorising and protecting rare species populations (e.g., the IUCN Red List) has been mostly based on information about their geographic range, population size and population structure (Fontaine \& al., 2007; Bilz \& al., 2011). Therefore, knowing the habitats and environmental requirements is essential to infer on rare species current and future dynamics, and thus to support effective conservation measures (Lomba \& al., 2010; Wallin \& Svensson, 2012).

For our test species, meadow and tall scrub habitats exhibited the highest and the most variable values for N. pseudonarcissus subsp. nobilis individuals. Furthermore,

Table 7. Overview of the main results attained for evaluating population and community structure across habitats and environmental variables (climate-, topography-, land-use-, and soil-related). +, positive relation; -, negative relation. Blank cells indicate no significant relation or that the analysis was not applied; DCA1/ DCA2, indicate the cases in which a significant relation was found for the first (DCA1) or second (DCA2) DCA axis.

\begin{tabular}{|c|c|c|c|c|c|c|}
\hline \multirow[b]{3}{*}{ Habitats/environmental gradients } & \multicolumn{4}{|c|}{ Population structure } & \multicolumn{2}{|c|}{ Community structure } \\
\hline & \multirow[b]{2}{*}{$\begin{array}{c}\text { Number } \\
\text { individuals }\end{array}$} & \multicolumn{3}{|c|}{ Population traits } & \multirow[b]{2}{*}{$\begin{array}{c}\text { Species } \\
\text { richness }\end{array}$} & \multirow[b]{2}{*}{$\begin{array}{c}\text { Species } \\
\text { compositior }\end{array}$} \\
\hline & & $\begin{array}{c}\text { Population } \\
\text { condition }\end{array}$ & $\begin{array}{c}\text { Population } \\
\text { renewal }\end{array}$ & $\begin{array}{c}\text { Disturbance } \\
\text { renewal }\end{array}$ & & \\
\hline \multicolumn{7}{|l|}{ Patterns across sites } \\
\hline Tall scrub & + & & & & - & \\
\hline Wet heaths & - & & & & + & \\
\hline Intensive meadows & - & & & & + & \\
\hline Crop fields & - & & & & - & \\
\hline \multicolumn{7}{|l|}{ Patterns along regional gradients } \\
\hline Total precipitation & & - & & & - & \\
\hline Days of precipitation & - & - & - & & - & \\
\hline Altitude & & & & & - & DCA1 \\
\hline \multicolumn{7}{|c|}{ Patterns along local and sub-local gradients } \\
\hline Land-use intensity & & & - & - & & DCA1 \\
\hline $\mathrm{pH}$ & & & & - & & DCA1 \\
\hline Organic matter & & + & + & - & & DCA1 \\
\hline \multicolumn{7}{|l|}{ Phosphorous } \\
\hline Potassium & & & - & & & DCA2 \\
\hline Magnesium & - & - & - & & & \\
\hline Nitrogen & & & & & - & DCA2 \\
\hline
\end{tabular}


traits expressing population capability for future renewal were negatively related to the increase of land-use intensity and specifically, soil organic matter and nutrient inputs. These results are in agreement with those from Wallin \& Svensson (2012), which reported higher population growth rates of a typical meadow plant (Succisa pratensis) in traditionally managed meadows from Gotland. Also, Lindborg \& Ehrlén (2002) indicated the disappearance of Primula farinosa (a meadow herb) under increasing levels of land fertilisation associated to more intensive meadow management and grazing in Sweden. The traditional meadow management usually includes a mowing period, which contributes to soil nutrient enrichment, and can constitute an advantage for bulbous plants (Klimek \& al., 2007; Winter \& al., 2011; Wallin \& Svensson, 2012). Our results seem to express the species preference for traditionally managed meadows (Honrado \& al., 2002). Also, the species affinity for successional habitat types (tall scrub), suggests that even under potential scenarios of meadow abandonment (Bielsa, 2005; Lomba \& al., 2012) the species could persist. Also, the high population variability observed (expressed by the inter-quartile range), might also highlight the fine-scale niche preferences and the ability of microhabitat occupancy by subsp. nobilis, suggesting a geographical heterogeneous expression of the populations' pool ("habitat filtering”) even within the same habitat type (Kleyer \& al., 2012).

The relations between individual population traits and regional environmental variables also suggest that climate is a significant factor for variations in population traits related to their current condition and future trends (renewal capability). These results likely indicate that future changes in climatic conditions, predicted to include a general increase of temperatures and a decrease of precipitation across the study area (Santos \& al., 2001), could influence the dynamics of the targeted populations.

\section{Community structure for multiple habitat types}

Information on the factors which directly affect the structure of populations might not always be enough to support rare species monitoring, as changes in population dynamics may be recognised too late (Broennimann \& al., 2005; Regnery \& al., 2013). Accordingly, complementary focus on the habitat/community structure and determinants could allow the identification of early-indicators on potential threats to the rare species (Bilz \& al., 2011; Halada \& al., 2011; Lindborg \& Ehrlén, 2002), as well as the accomplishment of further conservation goals such as those included in the "Habitats Directive" (E.U. Directive 92/43/CEE).

In our study, plant communities surveyed in sites dominated by meadows and wet heaths exhibited higher species richness compared to tall scrub and crop fields. These results are in agreement with those from Baur \& al. (2006) which reported higher values for red listed plant in seminatural and extensively managed hay meadows compared to abandoned habitats in Eastern Europe. Also, Lomba \& al. (2012) highlighted extensively managed meadows as important habitats for the maintenance of plant diversity when forecasting the decline of species richness under scenarios of long-term meadow abandonment in Northern Portugal. Several researchers already highlighted traditional land-use as an important supporter of plant diversity (Baur \& al.,
2006; Klimek \& al., 2007; Vassilev \& al., 2011; GonzálezOreja \& al., 2013). Traditional meadow management often comprises hay-cutting periods with aftermath raking, grazing and vegetation re-growth (Halada \& al., 2011; Lomba \& al., 2012; Wallin \& Svensson, 2012). Also, wet heaths are usually under domestic cutting, grazing and burning episodes (Hampton, 2008). These management options, coupled with e.g., invasive plant removal (Wallin \& Svensson, 2012) could promote intermediate levels of disturbance (Bratli \& al., 2006; Klimek \& al., 2007), and thus higher environmental heterogeneity e.g., related to distinct nutrient and light exposure conditions (Wallin \& Svensson, 2012; González-Oreja \& al., 2013). Accordingly, higher species diversity would be expected, as plant competitors would not be able to dominate, and thus an assortment of ecological niches for plant species with distinct resource needs and preferences becomes available (Enyedi \& al., 2008; Wallin \& Svensson, 2012). Shifts in these traditional practices, towards intensification or abandonment, have been reported as major determinants of plant diversity (Kleijn \& al., 2011; Plieninger \& al., 2014). This has been more explicit for land-use intensification, promoting landscape/habitat homogenisation (e.g., monoculture production; Bielsa \& al., 2005), fragmentation (e.g., patchiness of agricultural fields; Bratli \& al., 2006) and degradation (e.g., input of fertilisers or animal effluents; Vassilev \& al., 2011; Lomba \& al., 2012). For land-use abandonment, there is no agreement on its effects on plant diversity (Plieninger \& al., 2014), as some studies have been reporting the decline of diversity at long-term (Halada \& al., 2011; Vassilev \& al., 2011), but others suggesting their increase at short-terms (Bielsa \& al., 2005; Enyedi \& al., 2008). In our case, the intensification of meadow management and the prevalence of rather intensively managed habitats (wet heaths) seem to support plant diversity. This suggests that under more intensive, yet traditional agricultural regimes, plant diversity might be benefited. Contrastingly, conversion from traditionally managed habitats to other successional habitats (tall scrub) appears to promote a decline of plant diversity.

In respect to the environmental variables considered, community species richness was found to relate negatively to climatic (temperature and precipitation) and altitudinal shifts. Nevertheless, variations in plant composition were observed across a land-use gradient, with topography, soil $\mathrm{pH}$ and organic matter also showing a relevant relation. These results partially converge with those from Klimek \& al. (2007) which reported the joint effect of environmental context and management regimes as determinants of vegetation patterns along several managed grasslands in Germany. Also, Dietschi \& al. (2007) reported differences between plant community diversity from mountain meadows and grasslands along gradients of management intensity in Switzerland. Our results likely express the fact that the surveyed sites spread over a geographically heterogeneous area (Klimek \& al., 2007; Billeter \& al., 2008). Nevertheless, they also seem to reveal the effects of multi-scalar environmental filters, with: (1) broad scale climate and topography acting as filters for the regional species pool which is able to occur at smaller scales (Albert \& al., 2010; Kleyer $\&$ al., 2012), and (2) local land-use (and underlying regime options) limiting the abundance of each community plant species according to their ability for niche occupancy at 
fine-scales (Klimek \& al., 2007). Accordingly, a deeper assessment of sub-local features of our habitats could provide deeper insights on community patterns, habitat quality, and environmental pressures (Dietschi \& al., 2007; Halada \& al., 2011; González-Oreja \& al., 2013).

\section{Implications for the conservation of N. pseudonarcissus subsp. nobilis populations}

Extensively managed areas across rural landscapes often host species-diverse plant communities (Cousins \& Lindborg, 2004; González-Oreja \& al., 2013). Here, the diversity patterns of both plant population and community were found to be positively related to these traditional agricultural systems. Moreover, under the conversion of land-use regimes, a duality of situations appears to emerge. At the one hand, the intensification of such traditional practices seems to promote the diversity of plant communities. At the other hand, the extensification of agricultural practices could still allow the viability and prevalence of subsp. nobilis populations, as previously highlighted for other bulbous plants, such as Colchicum autumnale in Austria (Winter \& al., 2011).

We suggest that conservation measures should aim to maintain traditional agricultural practices in extensive hay meadows in order to promote the stability of subsp. noblis populations, where clonal reproduction plays an important role. In order to avoid future declines in population viability within each surveyed site, appropriate management measures should be adopted to favour clonality and increase population sizes. Specifically, we suggest that management measures should avoid land use intensification, namely restricting fertilizer inputs and ploughing practices in the currently occupied hay meadows, since these land use practices could compromise the integrity of the bulbs and cause local extinctions in otherwise stable populations. By adopting these measures, both clonal growth within populations, and sexual reproduction between sub-populations could be promoted, as highlighted by Colling \& al. (2010) .

The conservation measures suggested are of high importance considering that agricultural change is a key determinant of current environmental shifts in the study area (Vassilev \& al., 2011; Plieninger \& al., 2014). In fact, the maintenance of traditional and low-intensive agricultural systems such as High Nature Value farmlands have being explicitly targeted by EU environmental policies e.g., through the Common Agricultural Policy and the Rural Development Programmes (Dietschi \& al., 2007; Kleijn \& al., 2011; Lomba \& al., 2014). Accordingly, we support the fact that conservation efforts towards the maintenance of extensive land use practices in hay meadows from High Nature Value farmlands could constitute a win-win scenario for the subsp. nobilis populations and the habitats supported. This is also of high relevance considering not only the conservation status of the focal rare species, but also that the highly-rich habitats supported by the High Nature Value farmlands are under legal protection, E.U. Directive 92/43/CEE. The habitat types listed in Annex I of the Habitats Directive correspond to the surveyed habitats: 6510, "Lowland hay meadows (Alopecurus pratensis, Sanguisorba officinalis)" (hay meadows); and 4020*, "Temperate Atlantic wet heaths with Erica ciliaris and Erica tetralix" (Halada \& al., 2011). Nevertheless, as a relevant influence from regional climate was perceived, the role of climate change should not be devaluated on the future trends for the populations and habitats.

\section{Applying the framework to improve adaptive conservation management of $\mathrm{N}$. pseudonarcissus subsp. nobilis}

This research highlights the advantages of considering both population and community structure when planning conservation action aiming at fostering the persistence of rare species under multi-scale environmental change. For example, monitoring approaches targeting the effects of climate change on the populations of our test species could prioritise data collection on plant community species richness and on traits related to population condition; whereas management options involving land-use changes should consider information on community composition and on traits expressing population renewal.

Future efforts should focus on adapting the framework presented here for a wide range of species using spatiallyexplicit data and modelling techniques e.g., under scenarios of land-use and climate change over higher data resolution and through several periods of time (Lomba \& al., 2010; Vicente \& al., 2011; Lomba \& al., 2012). Even so, we advocate that our framework provides a suitable approach for reporting the condition and dynamics of rare plants, with high potential to contribute to more effective conservation and management programmes targeting populations of rare plants, especially in those landscapes where human management shows a major influence on biodiversity.

\section{ACKNOWLEDGEMENTS}

This work was supported by FCT (Portuguese Science and Technology Foundation) and COMPETE under Grant PTDC/AGRAAM/104819/2008. A. S. Vaz is supported by FSE/MEC (Ministério da Educação e Ciência/Fundo Social Europeu) and the Portuguese Science and Technology Foundation (FCT) through PhD Grant PD/BD/52600/2014 A. Lomba and J.R. Vicente were supported by POPH/FSE funds and by National Funds through FCT through Post-doctoral grants SFRH/BPD/ 80747/2011 and SFRH/BPD/84044/2012, respectively.

\section{REFERENCES}

Aedo, C. 2013. Narcissus L. in Rico, E, Crespo, M.B., Quintanar A. Aedo, C. (eds.). Flora iberica 20:340-397. Real Jardín Botánico, CSIC, Madrid.

Aguiar, C., Honrado, J. \& Soutinho, A.D. 2000. Comunidades e complexos de vegetação pratense do Noroeste de Portugal. Pastagens e Forragens 21: 29-50.

Albert, C.H., Thuiller, W., Yoccoz, N.G., Douzet, R., Aubert, S. \& Lavorel, S. 2010. A multi-trait approach reveals the structure and the relative importance of intra- vs. interspecific variability in plant traits. Functional Ecology 24: 1192-1201. http://dx.doi. org/10.1111/j.1365-2435.2010.01727.x

Barkham, J.P. 1980a. Population dynamics of the wild daffodil (Narcissus pseudonarcissus). I. Clonal growth, seed reproduction, mortality and the effects of density. Journal of Ecology 68: 607-633. http://dx.doi. org/10.2307/2259425

Barkham, J.P. 1980b. Population dynamics of the wild daffodil (Narcissus pseudonarcissus). II. Changes in number of shoots and flowers, and the effect of bulb depth on growth and reproduction. Journal of Ecology 68: 635-664. http://dx.doi.org/10.2307/2259426

Barkham, J.P. 1992. Population dynamics of the wild daffodil (Narcissus pseudonarcissus). IV. Clumps and gaps. Journal of Ecology 80: 797-808. http://dx.doi.org/10.2307/2260867 
Baur, B., Cremene, C., Groza, G., Rakosy, L., Schileyko, A.A., Baur, A. Stoll, P. \& Erhardt, A. 2006. Effects of abandonment of subalpine hay meadows on plant and invertebrate diversity in Transylvania, Romania. Biological Conservation 132: 261-273. http://dx.doi.org/10.1016/j. biocon.2006.04.018

Bielsa, I., Pons, X. \& Bunce, B. 2005. Agricultural abandonment in the North Eastern Iberian Peninsula: the use of basic landscape metrics to support planning. Journal of Environmental Planning and Management 48: 85-102. http://dx.doi.org/10.1080/0964056042000308166

Billeter, R., Liira, J., Bailey, D., Bugter, R., Arens, P., Augenstein, I., Aviron, S., Baudry, J., Bukacek, R., Burel, F., Cerny, M., de Blust, G., de Cock, R., Diekötter, T., Dietz,H., Dirksen, J., Dormann, C., Durka, W., Frenzel, M., Hamersky, R., Hendrickx, F., Herzog, F., Klotz, S., Koolstra, B., Lausch, A., le Coeur, D., Maelfait, J.P., Opdam, P., Roubalova, M., Schermann, A., Schermann, N., Schmidt, T., Schweiger, O., Smulders, M.J.M., Speelmans, M., Simova, P., Verboom, J., van Wingerden, W.K.R.E., Zobel, M. \& Edwards, P.J. 2008. Indicators for biodiversity in agricultural landscapes: a pan-European study. Journal of Applied Ecology 45: 141-150. http://dx.doi.org/10.1111/j.1365-2664.2007.01393.x

Bilz, M., Kell, S.P., Maxted, N. \& Lansdown, R.V. 2011. European Red List of Vascular Plants. Publications Office of the European Union. Luxembourg.

Bratli, H., Økland, T., Økland, R.H., Dramstad, W.E., Elven, R., Engan, G., Fjellstad, W., Heegaard, E., Pedersen, O. \& Solstad, H. 2006. Patterns of variation in vascular plant species richness and composition in SE Norwegian agricultural landscapes. Agriculture, Ecosystems E Environment 114:270-286. http://dx.doi.org/10.1016/j.agee.2005.10.022

Broennimann, O., Vittoz, P., Moser, D. \& Guisan, A. 2005. Rarity types among plant species with high conservation priority in Switzerland Botanica Helvetica 115: 95-108. http://dx.doi.org/10.1007/s00035. 005-0713-z

Castroviejo, S. et al. 1986-2015. Flora iberica 1-18, 20-21. Real Jardín Botánico, CSIC, Madrid.

Colling, G., Hemmer, P., Bonniot, A., Hermant, S. \& Matthies, D. 2010 Population genetic structure of wild daffodils (Narcissus pseudonarcissus L.) at different spatial scales. Plant Systematics and Evolution 287: 99-111. http://dx.doi.org/10.1007/s00606-010-0298-x

Cornelissen, J.H.C., Lavorel, S., Garnier, E., Díaz, S., Buchmann, N., Gurvich, D.E. \& Reich, P.B., ter Steege, H., Morgan, H.D., van der Heijden, M.G.A., Pausas, J.G. \& Poorter, H .2003. A handbook of protocols for standardised and easy measurement of plant functional traits worldwide. Australian Journal of Botany 51: 335-380. http://dx.doi. org/10.1071/BT02124

Cousins, S.A.O. \& Lindborg, R. 2004. Assessing changes in plant distribution patterns-indicator species versus plant functional types. Ecological Indicators 4: 17-27. http://dx.doi.org/10.1016/j.ecolind.2003.11.002

Deutschewitz, K., Lausch, A., Kühn, I. \& Klotz S. 2003. Native and alien plant species richness in relation to spatial heterogeneity on a regional scale in Germany. Global Ecology and Biogeography 12: 299-311. http:// dx.doi.org/10.1046/j.1466-822X.2003.00025.x

Dietschi, S., Holderegger, R., Schmidt, S.G. \& Linder, P. 2007. Agrienvironment incentive payments and plant species richness under different management intensities in mountain meadows of Switzerland. Acta Oecologica 31: 216-222. http://dx.doi.org/10.1016/j.actao.2006.10.006

Enyedi, Z.M., Ruprecht, E. \& Deák, M. 2008. Long-term effects of the abandonment of grazing on steppe-like grasslands. Applied Vegetation Science 11: 55-62. http://dx.doi.org/10.1111/j.1654-109X.2008.tb00204.x

ESRI. 2010. ArcGIS 10.0. Environmental Systems Research Institute Inc.

Fontaine, B., Bouchet, P., van Achterberg, K., Alonso-Zarazaga, M.A., Araujo, R., Asche, M., Aspöck, U., Audisio, P., Aukema, B., Bailly, N., Balsamo, M., Bank, R.A., Barnard, P., Belfiore, C., Bogdanowicz, W., Bongers, T., Boxshall, G., Burckhardt, D., Camicas, J.-L., Chylarecki, P., Crucitti, P., Deharveng, L., Dubois, A., Enghoff, H., Faubel, A., Fochetti, R., Gargominy, O., Gibson, D., Gibson, R., Gómez López, M.S., Goujet, D., Harvey, M.S., Heller, K.-G., van Helsdingen, P., Hoch, H., de Jong, H., de Jong, Y., Karsholt, O., Los, W., Lundqvist, L., Magowski, W., Manconi, R., Martens, J., Massard, J.A., MassardGeimer, G., McInnes, S.J., Mendes, L.F., Mey, E., Michelsen, V., Minelli, A., Nielsen, C., Nieto Nafría, J.M., van Nieukerken, E.J., Noyes, J., Pape, T., Pohl, H., de Prins, W., Ramos, M., Ricci, C., Roselaar, C., Rota, E., Schmidt-Rhaesa, A., Segers, H., Strassen, R.Z., Szeptycki, A., Thibaud, J.-M., Thomas, A., Timm, T., van Tol, J., Vervoort, W. \& Willmann, R. 2007. The European union's 2010 target: Putting rare species in focus. Biological Conservation 139: 167-185. http://dx.doi. org/10.1016/j.biocon.2007.06.012
Gondard, H., Jauffret, S., Aronson, J. \& Lavorel, S. 2003. Plant functional types: a promising tool for management and restoration of degraded lands. Applied Vegetation Science 6: 223-234. http://dx.doi.org/10.1111/ j.1654-109X.2003.tb00583.x

González-Oreja, J.A., Garbisu, C., Mijangos, I., Mendarte, S. \& Albizu, I. 2013. Reducing costs in biodiversity monitoring: Shortcuts for plant diversity in meadows as a case study. Ecological Indicators 24: 96-104. http://dx.doi.org/10.1016/j.ecolind.2012.06.008

Halada, L., Evans, D., Romão, C. \& Petersen, J.-E. 2011. Which habitats of European importance depend on agricultural practices? Biodiversity Conservation 20: 2365-2378. http://dx.doi.org/10.1007/ s10531-011-9989-z

Hampton, M. 2008. Management of Natura 2000 babitats. 4010 Northern Atlantic wet heaths with Erica tetralix. Technical Report 2008 08/24. European Commission.

Hanks, G.R. 2002. Narcissus and Daffodil: The Genus Narcissus. Taylor \& Francis Inc.. New Fetter Lane. London.

Hoare, J.M., Monks, A. \& O’Donnell, C.F.J. 2013. Do population indicators work? Investigating correlated responses of bird populations in relation to predator management. Ecological Indicators 25: 23-34. http://dx.doi. org/10.1016/j.ecolind.2012.09.007

Honrado, J.P., Alves, P., Alves, H.N. \& Caldas, F.B. 2002. Natural and semi-natural vegetation of the "Alto Minho". In: Honrado JP, Alves HN, Caldas FB, editors. Flora and Vegetation of the "Alto Minho". Excursion Guide of the "IV ALFA Meeting".: Associação Lusitana de Fitossociologia. pp 18-57. Porto.

ICNF. 2006. Plano sectorial da Rede Natura 2000. Fichas de caracterização e gestão das espécies constantes do anexo II da Directiva Habitats. [URL]: http://www.icnf.pt/portal/naturaclas/rn2000/p-set (Accessed 21 November, 2014).

ICNF. 2012. Sítios de importância comunitária: A Rede Natura 2000 em Portugal. Lisbon, Portugal. [URL]: http://www.icnf.pt/portal/naturaclas/cart/ap-rn-ramsar-pt (Accessed $21^{\text {st }}$ November, 2014).

Kent, M. \& Coker, P. 1992. Vegetation description and analysis: a practical approach. Wiley-Blackwell, West Sussex. UK.

Kleijn, D., Rundlöf, M., Scheper, J., Smith, H.G. \& Tscharntke, T. 2011. Does conservation on farmland contribute to halting the biodiversity decline? Trends in Ecology and Evolution 26: 474-481. http://dx.doi. org/10.1016/j.tree.2011.05.009

Kleyer, M., Dray, S., Bello, F., Lepš, J., Pakeman, R.J., Strauss, B., Thuiller, W. \& Lavorel, S. 2012. Assessing species and community functional responses to environmental gradients: Which multivariate methods? Journal of Vegetation Science 23: 805-821. http://dx.doi. org/10.1111/j.1654-1103.2012.01402.x

Klimek, S., gen. Kemmermann, A.R., Hofmann, M. \& Isselstein, J. 2007. Plant species richness and composition in managed grasslands: The relative importance of field management and environmental factors. Biological Conservation134: 559-570. http://dx.doi.org/10.1016/j. biocon.2006.09.007

Lavorel, S., Grigulis, K., Lamarque, P., Colace, M.-P., Garden, D. Girel, J., Pellet, G. \& Douzet, R. 2011. Using plant functional traits to understand the landscape distribution of multiple ecosystem services. Jounal of Ecology 99: 135-147. http://dx.doi. org $/ 10.1111 / \mathrm{j} .1365-2745.2010 .01753$.x

Lindborg, R. \& Ehrlén, J. 2002. Evaluating the Extinction Risk of a Perennial Herb: Demographic Data versus Historical Records. Conservation Biology 16: 683-690. http://dx.doi.org/10.1046/j.15231739.2002.00509.x

Lomba, A., Gonçalves, J., Moreira, F. \& Honrado, J. 2012. Simulating longterm effects of abandonment on plant diversity in Mediterranean mountain farmland. Plant Biosystems 147: 1-19.

Lomba, A., Pellissier, L., Randin, C., Vicente, J., Moreira, F., Honrado, J. \& Guisan, A. 2010. Overcoming the rare species modelling paradox: A novel hierarchical framework applied to an Iberian endemic plant. Biological Conservation 143: 2647-2657. http://dx.doi.org/10.1016/j. biocon.2010.07.007

Lomba, A., Guerra, C., Alonso, J., Honrado, J.P., Jongman, R. \& McCracken, D. 2014. Mapping and monitoring High Nature Value farmlands: Challenges in European landscapes. Journal of Environmental Management. 143: 140-50. http://dx.doi.org/10.1016/j. jenvman.2014.04.029

Lozano, F.D., Herbada, D.G., Rivero, L.M., Saiz, J.C.M. \& Ollero, H.S 1996. Threatened plants in Peninsular and Balearic Spain: A report based on the EU Habitats Directive. Biological Conservation 76: 123 133. http://dx.doi.org/10.1016/0006-3207(95)00107-7 
Moreira, A. \& Ribeiro, M.L. 1991. Carta Geológica do Parque Nacional da Peneda-Gerês à escala 1/50000. Serviços Geológicos de Portugal e Serviço Nacional de Parques Reservas e Conservação da Natureza.

Plieninger, T., Hui, C., Gaertner, M. \& Huntsinger, L. 2014. The impact of land abandonment on species richness and abundance in the Mediterranean Basin: A Meta-Analysis. PLoS ONE 9: e98355. http:// dx.doi.org/10.1371/journal.pone.0098355

Quinn, G.P. \& Keough, M.J. 2002. Experimental design and data analysis for biologists. Press Syndicate of the University of Cambridge. UK. http:// dx.doi.org/10.1017/CBO9780511806384

Regnery, B., Couvet, D. \& Kerbiriou, C. 2013. Offsets and conservation of the species of the EU Habitats and Birds Directives. Conservation Biology 27: 1335-1343. http://dx.doi.org/10.1111/cobi.12123

Rodríguez-Rojo, M.P. \& Sánchez-Mata, D. 2004. Mediterranean hay meadow communities: diversity and dynamics in mountain areas throughout the Iberian Central Range (Spain). Biodiversity Conservation 13: 2361-2380. http://dx.doi.org/10.1023/B:BIOC.0000047918.00589.90

Santos, F.D., Forbes, K. \& Moita, R.. 2001. Climate Change in Portugal. Scenarios, Impacts and Adaptation measures. SIAM. Executive Summary and Conclusions. Fundação Calouste Gunbenkian. Lisboa.

Schneiders, A., van Daele, T., van Landuyt, W. \& van Reeth, W. (2012) Biodiversity and ecosystem services: Complementary approaches for ecosystem management? Ecological Indicators 21: 123-133. http:// dx.doi.org/10.1016/j.ecolind.2011.06.021

Shipley, B., Vile, D. \& Garnier, É. 2006. From plant traits to plant communities: A statistical mechanistic approach to biodiversity. Science 314: 812-814. http://dx.doi.org/10.1126/science.1131344

Smart, S.M., Henrys, P.A., Purse, B.V., Murphy, J.M., Bailey, M.J. \& Marrs, R.H. 2012. Clarity or confusion? Problems in attributing large-scale ecological changes to anthropogenic drivers. Ecological Indicators 20: 51-56. http://dx.doi.org/10.1016/j.ecolind.2012.01.022

ter Braak, C.J.F. \& Smilauer, P. 2002. CANOCO Reference Manual and Canodraw for Window's User's Guide: Software for Canonical Community Ordination (version 45). Ithaca. NY.

Vassilev, K., Pedashenko, H., Nikolov, S.C., Apostolova, I. \& Dengler, J. 2011. Effect of land abandonment on the vegetation of upland semi-natural grasslands in the Western Balkan Mts, Bulgaria. Plant Biosystems 145: 654-665. http://dx.doi.org/10.1080/11263504.2011.601337

Vicente, J., Randin, C.F., Gonçalves, J., Metzger, M.J., Lomba, A., Honrado, J. \& Guisan, A. 2011. Where will conflicts between alien and rare species occur after climate and land-use change? A test with a novel combined modelling approach. Biological Invasions 13: 209-1227. http:// dx.doi.org/10.1007/s10530-011-9952-7

Violle, C., Navas, M.-L., Vile, D., Kazakou, E., Fortunel, C., Hummel, I. \& Garnier, E. 2007. Let the concept of trait be functional! Oikos 116: 882 892. http://dx.doi.org/10.1111/j.0030-1299.2007.15559.x

Wallin, L. \& Svensson, B. 2012. Reinforced traditional management is needed to save a declining meadow species: a demographic analysis. Folia Geobotanica 47: 231-247. http://dx.doi.org/10.1007/s12224-0129123-3

Winter, S., Penker, M. \& Kriechbaum, M. 2011. Integrating farmers' knowledge on toxic plants and grassland management: a case study on Colchicum autumnale in Austria. Biodiversity and Conservation 20: 1763-1787. http://dx.doi.org/10.1007/s10531-011-0060-x

Associate Editor: Javier Fuertes Received: 21-XI-2014 Accepted: 22-XII-2015 

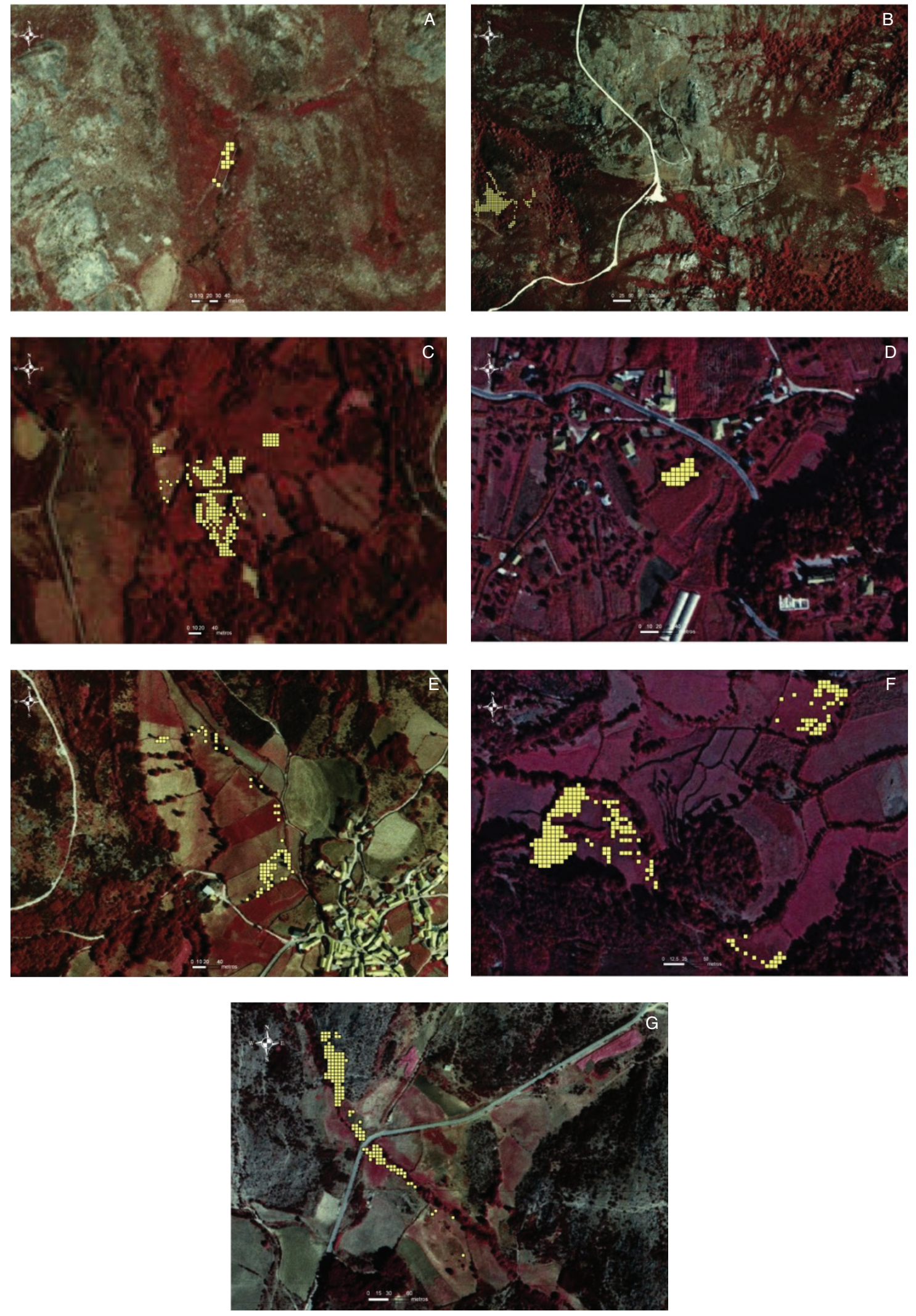

Appendix 1. Aerial imagery (http://scrif.igeo.pt/servicos/localiz/) considered for each Narcissus pseudonarcissus populations: Louriça, A; Lagoas do Marinho, B; Padroso, C; Sá, D; Sezelhe, E; Soutelo, F; and Videmonte, G. The fig. also shows the $25 \mathrm{~m}^{2} \mathrm{grid}$ cells which represent the location of $N$. pseudonarcissus subsp. nobilis individuals 
Appendix 2. Results from the post-hoc Mann-Whitney tests regarding differences for the values of species richness and N. pseudonarcissus subsp. nobilis individuals across surveyed populations. [n.s.] stands for non-significant values. All the other values exhibited in the table refer to the statistical significance (p) of the pair-wise Mann-Whitney test.

Community species richness - Kruskal-Wallis: $\mathrm{H}(n=35)=22.44, p=0.001$

\begin{tabular}{|c|c|c|c|c|c|c|c|}
\hline Surveyed sites & $\begin{array}{c}\text { Lagoas do } \\
\text { Marinho }\end{array}$ & Louriça & Padroso & Sá & Sezelhe & Soutelo & Videmonte \\
\hline Lagoas do Marinho & - & {$[n . s]$.} & 0.05 & 0.03 & {$[n . s]$.} & {$[n . s]$.} & 0.02 \\
\hline Louriça & [n.s.] & - & 0.60 & 0.03 & {$[$ n.s. $]$} & [n.s.] & [n.s.] \\
\hline Padroso & 0.05 & {$[$ n.s.] } & - & 0.02 & {$[$ n.s. $]$} & {$[$ n.s.] } & {$[$ n.s.] } \\
\hline Sá & 0.03 & 0.03 & 0.02 & - & {$[n . s]$.} & 0.02 & 0.01 \\
\hline Sezelhe & [n.s.] & [n.s.] & [n.s.] & [n.s.] & - & [n.s.] & 0.03 \\
\hline Soutelo & {$[$ n.s. $]$} & {$[$ n.s. $]$} & {$[$ n.s.] } & 0.02 & {$[$ n.s. $]$} & - & {$[$ n.s. $]$} \\
\hline Videmonte & 0.02 & {$[n . s]$.} & {$[$ n.s.] } & 0.01 & 0.03 & {$[$ n.s.] } & - \\
\hline
\end{tabular}

Number of $N$. pseudonarcissus subsp. nobilis individuals - Kruskal-Wallis: $\mathrm{H}(n=35)=17.75, p=0.0069$

\begin{tabular}{lccccccc}
\hline Surveyed sites & $\begin{array}{c}\text { Lagoas do } \\
\text { Marinho }\end{array}$ & Louriça & Padroso & Sá & Sezelhe & Soutelo & Videmonte \\
\hline Lagoas do Marinho & - & 0.01 & {$[$ n.s.] } & 0.01 & 0.03 & {$[$ n.s.] } & 0.01 \\
Louriça & 0.01 & - & {$[$ n.s.] } & {$[$ n.s.] } & 0.01 & 0.04 & 0.01 \\
Padroso & {$[$ n.s.] } & {$[$ n.s.] } & {$[$ n.s.] } & {$[$ n.s.] } & {$[$ n.s.] } & {$[$ n.s.] } & {$[$ n.s.] } \\
Sá & 0.01 & {$[$ n.s.] } & {$[$ n.s.] } & - & 0.01 & {$[$ n.s.] } & 0.01 \\
Sezelhe & 0.03 & 0.01 & {$[$ n.s.] } & 0.01 & - & 0.01 & {$[$ n.s.] } \\
Soutelo & [n.s.] & 0.04 & {$[$ n.s.] } & {$[$ n.s.] } & 0.01 & - & 0.01 \\
Videmonte & 0.01 & 0.01 & {$[$ n.s.] } & 0.01 & {$[$ n.s.] } & 0.01 & - \\
\hline
\end{tabular}


Appendix 3. List of the recorded species at each surveyed site. Nomenclature followed was that of Flora lberica (Castrovíejo et al., 1986-2001*). Sites: LMA, Lagoas do Marinho; LOU, Louriça; PAD, Padroso; SA, Sá; SEZ, Sezelhe; SOU, Soutelo; and VID, Videmonte.

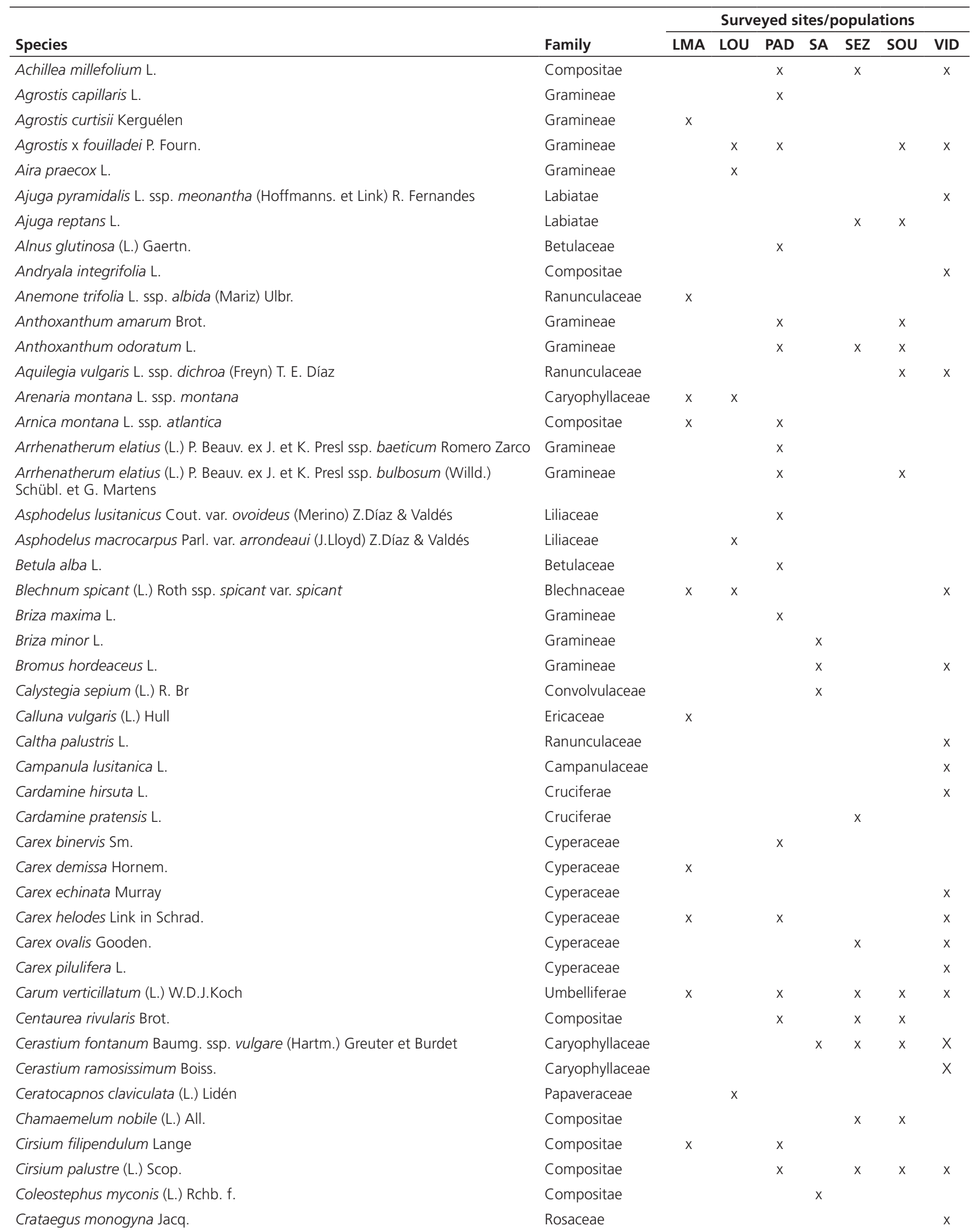


Appendix 3. (Continued)

\begin{tabular}{|c|c|c|c|c|c|c|c|c|}
\hline \multirow[b]{2}{*}{ Species } & \multirow[b]{2}{*}{ Family } & \multicolumn{7}{|c|}{ Surveyed sites/populations } \\
\hline & & LMA & LOU & PAD & SA & SEZ & SOU & VID \\
\hline Crepis capillaris (L.) Wallr. & Compositae & & & $x$ & $x$ & $x$ & $x$ & $x$ \\
\hline Cruciata glabra (L.) Ehrend. & Rubiaceae & & & & & & & $x$ \\
\hline Cynosurus cristatus L. & Gramineae & & & & & $x$ & & \\
\hline Cytisus striatus (Hill) Rothm. & Leguminosae & & & & & & & $x$ \\
\hline Dactylorhiza caramulensis (Vermeulen) Tyteca & Orchidaceae & $x$ & & $x$ & & $x$ & & $x$ \\
\hline $\begin{array}{l}\text { Dactylorhiza maculata (L.) Soó ssp. ericetorum (E. F. Linton) P. F. Hunt } \\
\text { et Summerh. }\end{array}$ & Orchidaceae & $x$ & & & & & & \\
\hline Danthonia decumbens (L.) DC. in Lam. et DC. & Gramineae & $x$ & & & & & $x$ & \\
\hline Deschampsia flexuosa (L.) Trin. & Gramineae & & $x$ & & & & & \\
\hline Echium Iusitanicum L. & Boraginaceae & & & $x$ & & $x$ & & $x$ \\
\hline Echium plantagineum $\mathrm{L}$. & Boraginaceae & & & & $x$ & & & \\
\hline Epilobium obscurum Schreb. & Onagraceae & & & & & $\mathrm{x}$ & & $x$ \\
\hline Erica arborea L. & Ericaceae & $\mathrm{x}$ & $x$ & & & & & $\mathrm{x}$ \\
\hline Erica australis L. & Ericaceae & $x$ & & & & & & \\
\hline Erica cinerea L. & Ericaceae & $x$ & $x$ & & & & & \\
\hline Erica tetralix L. & Ericaceae & $x$ & & & & & & \\
\hline Erica umbellata Loefl. ex L. & Ericaceae & $x$ & & & & & & \\
\hline Eriophorum angustifolium Honck. & Cyperaceae & $x$ & & & & & & \\
\hline Galium palustre L. & Rubiaceae & & & $x$ & & & & \\
\hline Galium pumilum Murray ssp. rivulare (Boiss. Et Reut.) O. Bolòs et Vigo & Rubiaceae & & & & & & & $x$ \\
\hline Galium harcynicum Weigel & Rubiaceae & & $x$ & & & & & \\
\hline Genista anglica L. & Leguminosae & & & & & & & $x$ \\
\hline Genista florida L. & Leguminosae & & $\mathrm{x}$ & & & & & \\
\hline Genista micrantha Ortega & Leguminosae & $x$ & & & & & & \\
\hline Geranium columbinum L. & Geraniaceae & & & $x$ & & & $x$ & \\
\hline Geranium dissectum L. & Geraniaceae & & & & $x$ & & & \\
\hline Geranium purpureum L. ssp. purpureum (Vill.) Nyman & Geraniaceae & & & $\mathrm{x}$ & & & & \\
\hline Gladiolus illyricus W. D. J. Koch & Iridaceae & & & $x$ & & & & \\
\hline Halimium lasianthum (Lam.) Spach ssp. alyssoides (Lam.) Greuter & Cistaceae & $x$ & $x$ & & & & & \\
\hline Hedera hibernica (G. Kirchn.) Bean & Araliaceae. & & & $x$ & & & & \\
\hline Heracleum sphondylium L. & Umbelliferae & & & & & $x$ & & \\
\hline Holcus lanatus L. & Gramineae & & $x$ & $x$ & $x$ & $x$ & $x$ & $x$ \\
\hline Holcus mollis $\mathrm{L}$. & Gramineae & & & & & $x$ & & $x$ \\
\hline Hyacinthoides hispanica (Mill.) Rothm. & Hyacinthaceae & & & & & $\mathrm{x}$ & & \\
\hline Hyacinthoides paivae S. Ortiz \& Rodr. Oubiña & Liliaceae & & $x$ & & & & & \\
\hline Hyacinthoides sp. & Liliaceae & $x$ & & & & & & $x$ \\
\hline
\end{tabular}


Appendix 3. (Continued)

\begin{tabular}{|c|c|c|c|c|c|c|c|c|}
\hline \multirow[b]{2}{*}{ Species } & \multirow[b]{2}{*}{ Family } & \multicolumn{7}{|c|}{ Surveyed sites/populations } \\
\hline & & LMA & LOU & PAD & SA & SEZ & SOU & VID \\
\hline Hypericum humifusum $\mathrm{L}$. & Clusiaceae & & & & & & & $\mathrm{x}$ \\
\hline Hypochoeris radicata $\mathrm{L}$. & Compositae & & & $x$ & & $x$ & $x$ & $x$ \\
\hline Ilex aquifolium L. & Aquifoliaceae & $x$ & $x$ & & & & & \\
\hline Iris pseudacorus L. & Iridaceae & & & & & & $x$ & \\
\hline Juncus acutiflorus Hoffm. & Juncaceae & & & $x$ & & $x$ & & $x$ \\
\hline Juncus bufonius L. & Juncaceae & & & & & & & $x$ \\
\hline Juncus effusus L. & Juncaceae & & & & & $x$ & & $x$ \\
\hline Leontodon taraxacoides ssp. Taraxacoides (Vill.) Mérat & Compositae & $x$ & & & & & & $x$ \\
\hline Linum usitatissimum L. angustifolium (Huds.) Thell. & Linaceae & & & $x$ & & & & \\
\hline Lonicera periclymenum ssp. Periclymenum L. & Caprifoliaceae & & $x$ & $x$ & & & & \\
\hline Lotus pedunculatus Cav. & Leguminosae & & & $x$ & & $x$ & $x$ & $x$ \\
\hline Luzula campestris (L.) DC. In Lam. Et DC. & Juncaceae & & & & & & & $x$ \\
\hline Luzula multiflora (Retz.) Lej. & Juncaceae & & & $x$ & & & & $x$ \\
\hline Malva tournefortiana L. & Malvaceae & & & & & & $x$ & \\
\hline Mentha suaveolens Ehrh. & Labiatae & & & & $x$ & $\mathrm{x}$ & $x$ & $x$ \\
\hline Montia fontana ssp. amporitana Sennen & Portulacaceae & & & & & & & $\mathrm{x}$ \\
\hline Myosotis balbisiana Jord. & Boraginaceae & & & & & & & $\mathrm{x}$ \\
\hline Myosotis discolor Pers. & Boraginaceae & & & & & $x$ & & \\
\hline Ornithopus compressus L. & Leguminosae & & & & & $x$ & & \\
\hline Ornithopus perpusillus L. & Leguminosae & & & & & $x$ & & $x$ \\
\hline Paradisea Iusitanica (P. Cout.) Samp. & Liliaceae & & & & & & & $x$ \\
\hline Parentucellia viscosa (L.) Caruel & Scrophulariaceae & & & & & & $x$ & \\
\hline Peucedanum lancifolium Lange & Umbelliferae & & & & $x$ & $x$ & & $x$ \\
\hline Phytolacca americana L. & Phytolaccaceae & & & & $x$ & & & \\
\hline Plantago lanceolata L. & Plantaginaceae & & & $x$ & & $x$ & $x$ & $x$ \\
\hline Poa trivialis $\mathrm{L}$. & Gramineae & & & & $x$ & $x$ & & $x$ \\
\hline Polygala serpyllifolia Hose & Polygalaceae & $x$ & & & & & & $x$ \\
\hline Potentilla erecta (L.) Raeusch. & Rosaceae & $x$ & & $x$ & & & $x$ & $x$ \\
\hline Prunella vulgaris $\mathrm{L}$. & Labiatae & & & $x$ & & & $x$ & $x$ \\
\hline Pseudarrhenatherum longifolium (Thore) Rouy & Gramineae & $x$ & & $x$ & & & & \\
\hline Pteridium aquilinum (L.) Kuhn & Dennstaedtiaceae & $x$ & $x$ & $x$ & $x$ & $\mathrm{x}$ & $x$ & $x$ \\
\hline $\begin{array}{l}\text { Pterospartum tridentatum (L.) Willk. ssp. cantabricum (Spach) Talavera et P. E. } \\
\text { Gibbs }\end{array}$ & Leguminosae & & $x$ & & & & & \\
\hline Pyrus cordata Desv. & Rosaceae & & & & & & $x$ & \\
\hline Quercus robur $\mathrm{L}$. & Fagaceae & & $x$ & $x$ & & & $x$ & \\
\hline Quercus x andegavensis Hy & Fagaceae & & & $x$ & & & & \\
\hline Ranunculus bulbosus subps. Adscendens (Brot.) P. Silva & Ranunculaceae & & & & & & & $x$ \\
\hline
\end{tabular}


Appendix 3. (Continued)

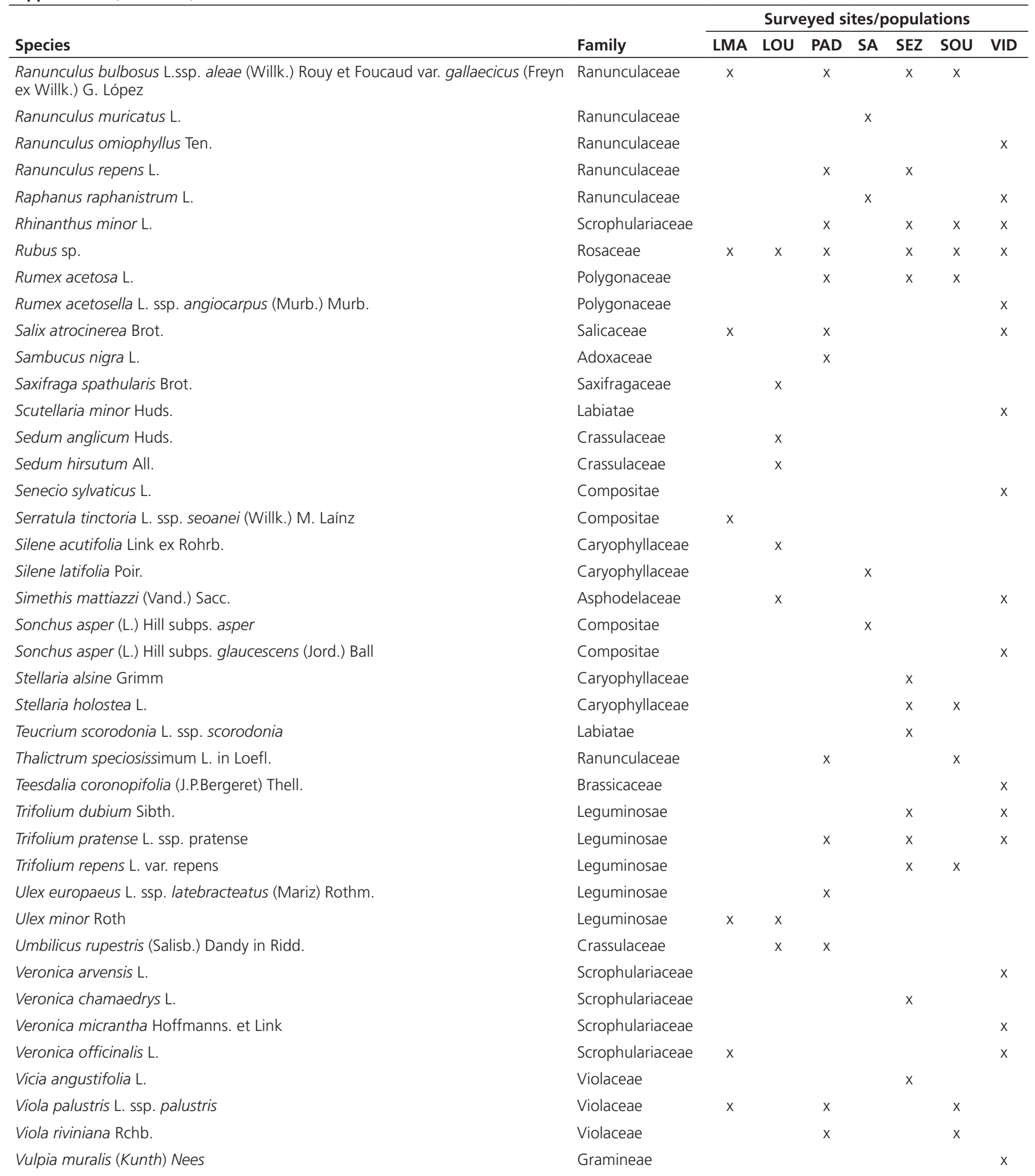

Castroviejo, S. et al. 1986-2015. 